\title{
An approximation to the study of black pigments in Cova Remigia (Castellón, Spain). Technical and cultural assessments of the use of carbon-based black pigments in Spanish Levantine Rock Art
}

\author{
Esther López-Montalvo ${ }^{\mathrm{a},}{ }^{*}$, Valentín Villaverde ${ }^{\mathrm{b}}$, Clodoaldo Roldán ${ }^{\mathrm{c}}$, Sonia Murcia ${ }^{\mathrm{c}}$, \\ Ernestina Badal ${ }^{\text {b }}$ \\ a CNRS UMR 5608 TRACES-Université de Toulouse II-Jean Jaurès. 5, Allée Antonio Machado, 31058 Toulouse, France \\ ${ }^{\mathrm{b}}$ Universitat de Valencia, Departament de Prehistòria i d'Arqueologia, Blasco Ibáñez, 28, 46010 Valencia, Spain \\ c Instituto de Ciencias de los Materiales, Universitat de Valencia (ICMUV), Catedrático José Beltrán 2, E46980 Paterna, Valencia, Spain
}

\section{A R T I C L E I N F O}

\section{Article history:}

Received 19 November 2013

Received in revised form

14 September 2014

Accepted 27 September 2014

Available online 8 October 2014

\section{Keywords:}

Rock art of the Spanish Levant

Neolithic

Valltorta-Gassulla

Black pigments

EDXRF analysis

Raman spectroscopy

SEM-EDS

\begin{abstract}
A B S T R A C T
Spanish Levantine Rock Art is a unique pictorial expression within the prehistoric European context. Located in shelters in the inland regions of the Iberian Mediterranean basin, this art form, which must be necessarily studied in the frame of the process of neolithization of this territory, still lacks direct dating, and therefore its authorship is still open to debate.

In this paper we present the first characterization of black pigments used in the Cova Remigia shelters in the Valltorta-Gassulla area (Castellón, Spain) by means of EDXRF spectrometry combined with SEMEDS and Raman spectroscopy. Our aim is both to identify the raw material used for the preparation of black pigments and to make a first approach to the cultural choices involved in its use.

The results are relevant for several reasons. Firstly, carbon-based black pigments have been identified for the first time in northern regions of Levantine rock art. Secondly, the recurrent use of black pigments in Cova Remigia questions the assumption of its restricted use in Spanish Levantine art. Thirdly, posterior repainting and graphic re-appropriation of black figures have been observed in Cova Remigia, giving rise to the combination of two colours, black and red, fact that is extremely rare in this rock art tradition. Finally, the identification of organic matter in the black pigments opens the possibility of radiocarbon dating.
\end{abstract}

(C) 2014 Elsevier Ltd. All rights reserved.

\section{Introduction}

The rock art of the Spanish Levant is a prehistoric graphic expression mostly documented in the Iberian Mediterranean basin. Discovered at the beginning of the 20th century, this art form is mainly characterized by the following features: it is located in open-air rock shelters, the human figure has a predominant role in scenes portraying economic and social activities and red pigments largely prevail (Cabré, 1915; Beltrán, 1968; Villaverde et al., 2012; etc.).

The chronology of Levantine paintings has been the subject of controversy. There are currently two main opposing views: some

\footnotetext{
* Corresponding author. Tel.: +33 5615047 55; fax: +33 561504959 .

E-mail addresses: esthermontalv@gmail.com, esther.lopez-montalvo@univtlse2.fr (E. López-Montalvo), valentin.villaverde@uv.es (V. Villaverde), clodoaldo. roldan@uv.es (C. Roldán), Sonia.Mascaros@uv.es (S. Murcia), ernestina.badal@uv. es (E. Badal).
}

studies claim that these paintings were produced by late Mesolithic hunters-gatherers, thus establishing a connection to the Palaeolithic tradition (Mateo Saura, 2005, 2009; Viñas et al., 2010; etc.), while others consider that this form of art belongs to the Neolithic agro-pastoral communities (Molina et al., 2003; García et al., 2004; Martí, 2003; Martí and Juan-Cavanilles, 2002, 2013). The first view is only supported by arguments regarding hunting themes, one of the main activities portrayed in Levantine art. In contrast, the second is based on both the archaeological context, regarding the spatial distribution of Levantine rock art shelters related to prehistoric population settlements, and on the graphical context, considering the Levantine motifs superimpositions on Early Schematic Art, dated to Neolithic period. The second point of view is also supported by the chronology suggested by the material culture and social and economic activities portrayed.

So far, research was mostly limited by two main practises: the selective recording of panels according to subjective criteria and studies focused on the interpretation of the meaning of scenes. 
However, in recent years, an improvement in the recording methods and in the study of rock art has taken place and has strongly contributed to provide a new insight into Levantine art. Two main achievements can be pointed out: a) the characterization of spatio-temporal changes concerning style, execution techniques and themes, revealing concurrently that engraving was also used in Levantine depictions (Utrilla and Villaverde, 2004); and b) the incorporation of Geographical Information Systems (GIS) in order to reconstruct the stylistic cartography and to assess the relation of stylistic horizons to other archaeological evidences. In fact, spatial analyses have become a fundamental archaeological procedure that could compensate for the difficulty of obtaining direct dating of paintings that were mainly executed with mineral pigments. Some attempts to date oxalate layers covering Levantine paintings have been carried out (Hernanz et al., 2006; Ruiz et al., 2006, 2009, 2011, 2012), but it is worth noting that these methods have certain limitations when applied to open-air panels.

In this paper we present new technical discoveries concerning the preparation mode and the utilization of black pigments in Levantine paintings. The study carried out in the Cova Remigia shelters allows us to confirm both that the black pigment, so far identified as a manganese-based pigment in the ValltortaGassulla region, was also obtained from organic materials and that black colour was more frequently used than what was previously thought, especially during some stylistic phases of Levantine rock art. The identification of carbon-based black pigments points to the possibility of radiocarbon dating representing a major step towards the resolution of the chronological controversy that has affected these prehistoric paintings since their discovery.

\section{Spanish Levantine rock art}

\subsection{Pigments: towards a deeper understanding of prehistoric societies}

The study of pigments is not limited to the mere identification of their chemical composition. Pigments are a potential source of information regarding the provenance of the raw materials and the technical processes used for their preparation and application (Pomiès et al., 1999; Chalmin et al., 2003; Menu, 2009; etc.). In short, knowing the various phases of the chaîne opératoire for the processing of pigments can help us to consider prehistoric societies from different angles: a) territories and exploited areas in an economic perspective; b) characterization of the technical processes for the preparation and application of pigments in a social perspective; c) emphasis on recurrent sequences of gestures revealing social practises. For instance, particular tradition and style, but also symbolic and ritual features, may be linked to the use of pigments. In addition to these socio-economic aspects, the presence of organic components offers the possibility of obtaining absolute radiocarbon dating.

Studies of pigments, despite of their interest, have received little attention in Levantine art. Systematic chemical analyses have only become essential in recent years (Roldán et al., 2007; Roldán, 2009; Alloza et al., 2009; Roldán et al., 2010; Hernanz et al., 2010; Vázquez et al., 2011; Mas et al., 2013; etc.). The attention was centred on the identification of the main components of the pigment and on the presence of trace elements that were characteristic of a particular shelter. Due to the large uniformity in the composition of the red pigments that are mostly used in Levantine tradition, pigment analyses have scarcely contributed to the temporal and stylistic assessments and to the characterization of territorial networks.

\subsection{The Levantine rock art artists' palette}

The Levantine rock art artists' palette is made up of three colours: red, black and white, but their frequency and territorial distribution are quite heterogeneous.

Red pigments are present throughout the whole temporal sequence and are widely prevailing throughout the Levantine rock art territory. Iron oxides (haematite) have so far been identified as the basic raw material for red pigments in the Valltorta-Gasulla area; these findings agree with those obtained in other Levantine regions (Hernanz et al., 2006; Resano et al., 2007; Alloza et al., 2009; Hernanz et al., 2010). The presence/absence of impurities or trace elements in these red pigments points to the use of different raw materials. In the Saltadora and the Cingle de la Mola Remigia shelters, we have analysed red pigments with reddish hues linked to the presence of manganese $(\mathrm{Mn})$, arsenic $(\mathrm{As})$ or lead $(\mathrm{Pb})$ as trace elements, or to the intentional addition of black manganese oxides (Roldán et al., 2010, 2014). However, we must take into consideration that the wide chromatic range found in red paints is not only due to chemical composition but also to the fossilization and weathering processes that these paintings have suffered.

White pigments are not frequently used. For monochrome figures, it has only been documented in the Albarracín area (Teruel) (Piñón Varela, 1982). As a complement to red colour, white pigments were also identified in Valltorta-Gassulla (Castellón) (Cabré, 1925; Villaverde et al., 2006; Domingo, 2006; López Montalvo, 2007) and in Villar del Humo-Sierra de las Cuerdas (Cuenca) (Ruiz, 2006). In these cases, white was used to highlight figures, to complete interior fillings or to add ornaments. In the light of these new findings, the infrequent use of white in the Spanish Levantine tradition might be questioned, especially because white is hard to observe in situ and is particularly sensitive to degradation factors. Regarding its chemical composition, recent analyses carried out at the Villar del Humo shelters (Cuenca) (Ruiz et al., 2012) have pointed to the use of a complex mixture of minerals such as anatase, quartz, and a type of white clay found at surface levels in the area (Hernanz et al., 2008, 2012).

Finally, black pigments are less common than red ones, but in contrast to white pigments, their use is not limited to some temporal sequences or to particular geographical areas. So far, in the Valltorta-Gasulla area, analyses have allowed identifying black pigments containing manganese oxides (Roldán et al., 2007, 2010). On the other hand, in southern Levantine regions, analyses have detected black pigments of carbonaceous nature (Montes and Cabrera, 1991-1992; Ballester et al., 2010). The denomination carbon-based black pigments includes many carbon-containing pigments, such as vegetable or plant blacks, ivory/bone black or animal black, lampblack, graphite, etc., regardless of whether it is the sole element or the main ingredient. Vegetable carbon pigments have been identified in prehistoric paintings since the Upper Palaeolithic (Clottes, 1993; Menu and Walter, 1996; Ospitali et al., 2006; Winter and West FitzHugh, 2007; Arias et al., 2011; Olivares et al., 2013 etc.). They could probably be the first carbon-based black pigments used in the history of humanity, since these pigments can be used directly as charcoal (vegetal carbon) or graphite (mineral carbon) sticks, without relying on binding agents making its application easier (Insert Supplementary Fig. 1 here).

\section{Experimental techniques}

\subsection{The study framework}

The data reported in this paper are the result of our work in Cova Remigia, a set of five shelters and a neighbouring wall, located in the Valltorta-Gasulla gorges (Castellón, Spain) (Fig. 1). 

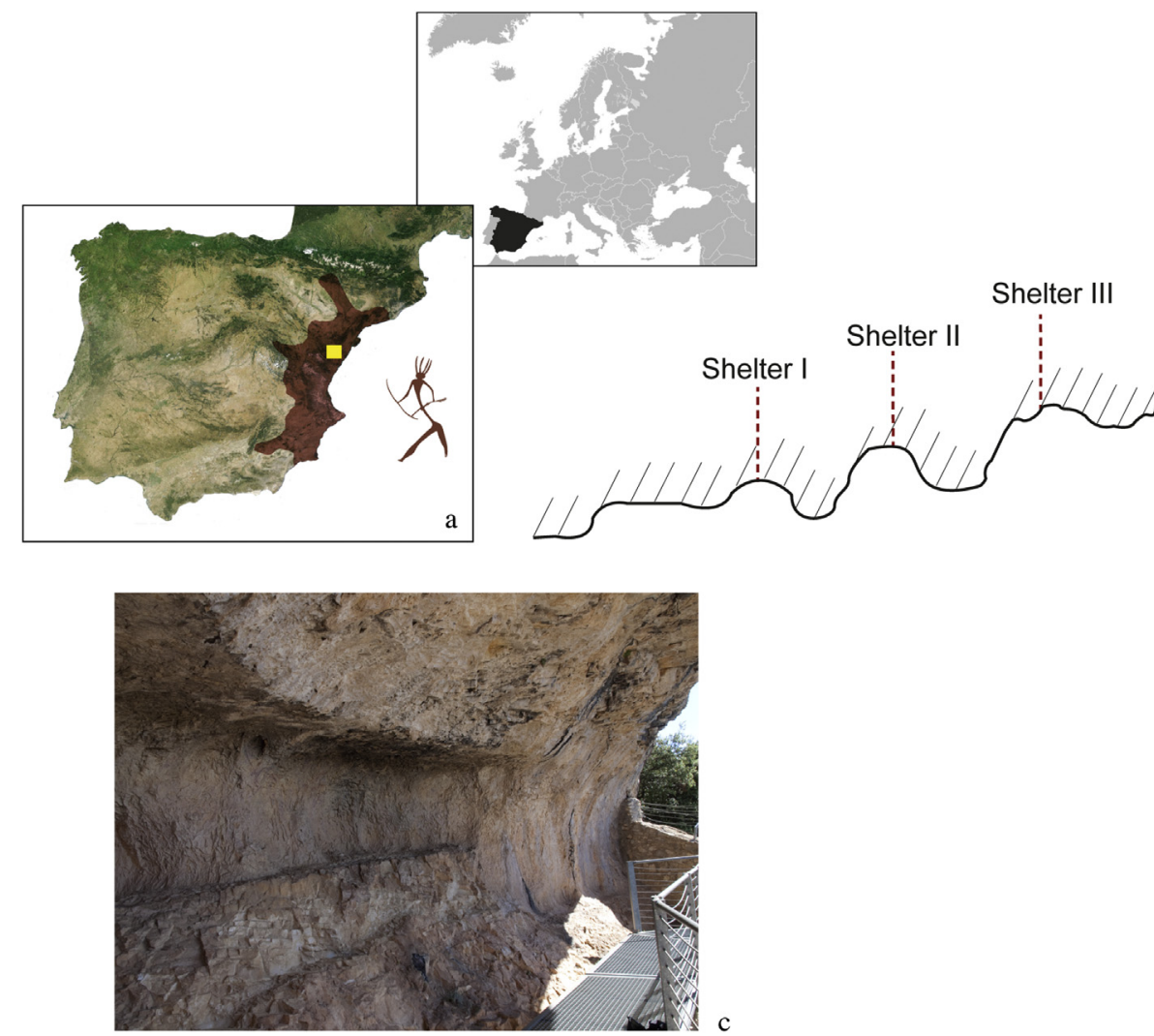

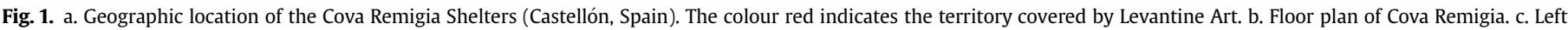

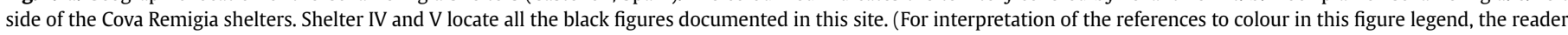
is referred to the web version of this article.)

The discovery of Cova Remigia in 1934 led to a monographic publication by J.B. Porcar et al. (1935). Subsequent work by E. Sarrià (Sarrià Boscovich, 1988-1989) considerably increased the number of known figures (975 motifs), making of this shelter the first assemblage in number of representations in the Valltorta-Gassulla region. Recent cleaning operations carried out as a preventive measure have revealed more motifs that were covered by dust and calcareous accretions.

Cova Remigia is not only important quantitatively. Its stylistic variety includes the five stylistic horizons so far characterized in the regional context by means of the formal and technical analysis of the human figure (Villaverde et al., 2002; Domingo et al., 2003; Domingo, 2006; Villaverde et al., 2006; Domingo et al., 2007; López Montalvo, 2007, 2009; etc.). Stylistic differences reflect a diachronic exploitation of panels in which figures from different phases are integrated in complex compositions with a common narrative thread. Concerning the theme of the scenes, Cova Remigia stands out for the representation of violent scenes that are not frequent in Levantine rock art (Porcar, 1945, 1946; López Montalvo, 2011a). Further technical factors related to the raw materials of pigments and the design of figures make of Cova Remigia an exceptional site.

\subsection{Spectroscopic techniques}

EDXRF analyses were performed on 52 points from 25 black motifs ( 34 points on black pigment and 18 points on the bare rock surface lacking of black pigmentation). These 25 motifs - 15 human figures, 6 animals, 1 animal track and 3 undefined motifs - have been selected among the 48 black figures documented in the site considering several criteria: conservation, relevant stylistic and technical information, as well as easy access for the analytical devices.

To study the elemental composition of black pigments, we have used two types of analyses: a) in situ and non-destructive analysis in order to preserve the integrity of paintings; and b) ex situ analysis on micro-samples of a limited set of black figures, due to restrictions of regional Heritage politics of preservation, in order to check the results of non-destructive analysis.

In situ analyses have been carried out by means of a portable Energy Dispersive X-ray Fluorescence (EDXRF) spectrometer (Roldán et al., 2010), which consists of an X-ray tube (Ag transmission anode, $30 \mathrm{kV}, 0.1 \mathrm{~mA}$ ) and a semiconductor Si-PIN detector with an energy resolution of $180 \mathrm{eV}$ (FWHM @ $5.9 \mathrm{keV}$ ). Both devices were incorporated into a mechanical support that allows XYZ movements in order to configure the angular geometry for the tube, the sample and the detector. The analyses were carried out with normal X-ray beam incidence on the sample, keeping the detector at a $45^{\circ}$ angle, and with an excitation-detection time of $200 \mathrm{~s}$. The distance between the sample and the detector was $2 \mathrm{~cm}$. An aluminium collimator placed at the end of the tube provided an irradiation area of $3 \mathrm{~mm}$ in diameter. EDXRF spectra were processed using the PyMCA software (Solé et al., 2007), and were normalized to the total area of the spectrum in order to diminish the importance of geometrical effects and fluctuations of the tube's intensity (Insert Supplementary Fig. 2 here).

Additionally, selected sub-millimetre micro-samples were obtained from black figures and were analysed by scanning electron microscopy-energy dispersive spectrometry (SEM-EDS) and Raman spectroscopy in order to get around the impossibility of identifying 
carbon-based black pigments by EDXRF spectrometry. Raman spectroscopy was undertaken using a HORIBA Jobin Yvon iHR320 spectrometer with a Peltier-cooled CCD detector and a $405 \mathrm{~nm}$ laser diode providing excitation with maximum power of $3 \mathrm{~mW}$. The samples were measured in backscattering geometry at room temperature. A $50 \times$ microscope objective was used to focus the excitation laser on the sample and registering the scattered light by the spectrometer. SEM-EDS analyses were performed by using an S4800 (HITACHI) scanning electron microscope with a spotlight of field emission (FEG) with a resolution of $1.4 \mathrm{~nm}$ at $1 \mathrm{kV}$ coupled with an energy-dispersive X-ray spectrometer (Bruker) for the elemental chemical analyses.

\section{Results and discussion}

\subsection{Technical analyses}

The structure of Levantine paintings in Cova Remigia can be described from a stratigraphic model that distinguishes three main layers whose thickness and composition play an important role in assessing the results of the EDXRF analyses: a) the limestone bedrock surface over which the pigments are applied, mainly composed by calcium carbonates, calcium sulphates and iron oxides, is considered as a material of infinite thickness from the point of view of the XRF radiation; b) a paint layer with a thickness of a few microns applied over the rock (Resano et al., 2007); and c) a surface patina that covers the motif itself, produced by the action of microorganisms or by the interaction between the wall and the environment. These patinas are mainly composed of oxalates, calcium carbonates or calcium sulphates, and their thickness reaches up to few tens of microns (Hernanz et al., 2006; Resano et al., 2007; Hernanz et al., 2010). The penetration depth of the XRF radiation into the surface patina, assuming a composition similar to oxalates $\left(\mathrm{CaC}_{2} \mathrm{O}_{4}\right)$ and a density of $2.2 \mathrm{~g} / \mathrm{cm}^{3}$, irradiated with a continuum Xray spectra of $30 \mathrm{kV}$ with a maximum of $20 \mathrm{keV}$ giving rise to $50 \%$ of fluorescence radiation, is about $700 \mu \mathrm{m}$. Thus, the radiation from the EDXRF spectrometer used in these analyses can penetrate the superficial patinas and excite the fluorescent radiation of the chemical elements present in the paint layer. However, the thickness of the superficial patina is a critical parameter that determines the possibility to detect the fluorescence radiation of the light elements from the pigment layer due to the attenuation created by the patina. Considering a paint layer whose elements emit a characteristic radiation of about $6 \mathrm{keV}$ (manganese or iron), an oxalate layer of $80 \mu \mathrm{m}$ thick would attenuate $90 \%$ of the emitted radiation. For lighter elements such as phosphorus, whose characteristic radiation has an energy of $2 \mathrm{keV}$, a patina of $20 \mu \mathrm{m}$ thick would attenuate $90 \%$ of the radiation from this element. Therefore, the optimal detection of chemical elements from a paint layer under a superficial patina depends on the thickness and composition of the patina. Over the paint layers of the Cova Remigia samples, superficial patinas with thickness ranging from 10 to $25 \mu \mathrm{m}$ have been detected, so the thickness of the superficial patinas must be taken into consideration for the identification of light elements such as phosphorous in a EDXRF spectra of a pictorial motif.

When X-rays have enough energy to penetrate through the patinas and the paint layer, the EDXRF spectrum of a motif includes, simultaneously, information about the composition of the pigment layer and the rock support elemental composition (Roldán et al., 2010). Analyses were carried out on selected points, recording the spectra of the rock surface and the spectra of black pigments separately. Discrimination between the characteristic elements of the pigment and those of the rock support was established by comparison of EDXRF spectra from the black pigment and from the unpainted rock surface next to the figure (Sanoit et al., 2005;
Roldán et al., 2010, 2013). If the EDXRF spectra from black figures are similar to the spectra from the close unpainted rock surface (in relation to the detected elements and intensity of their fluorescence lines), the pigment will probably be a charcoal black. On the other hand, if the spectra of the black pigmented area and the bare
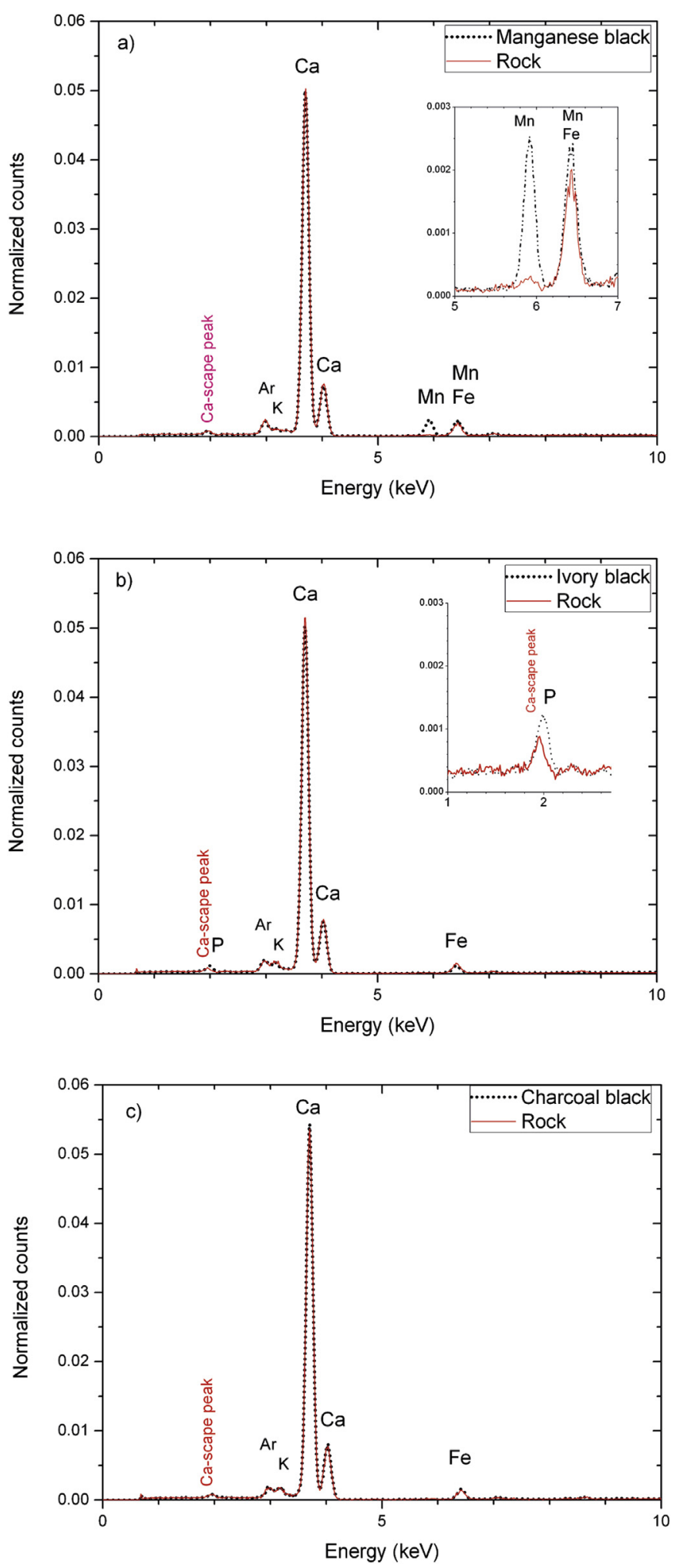

Fig. 2. EDXRF spectra of black pigments applied on a calcareous rock: a. manganese black; b. ivory black; c. charcoal black. 
rock surface are different, we can conclude that non-vegetable or plant based black pigments were used as raw material. When Mn is the distinctive element, we postulate the use of manganese-based black pigment, and when the distinctive element is phosphorus, probably a bone-based black pigment was used. To illustrate the
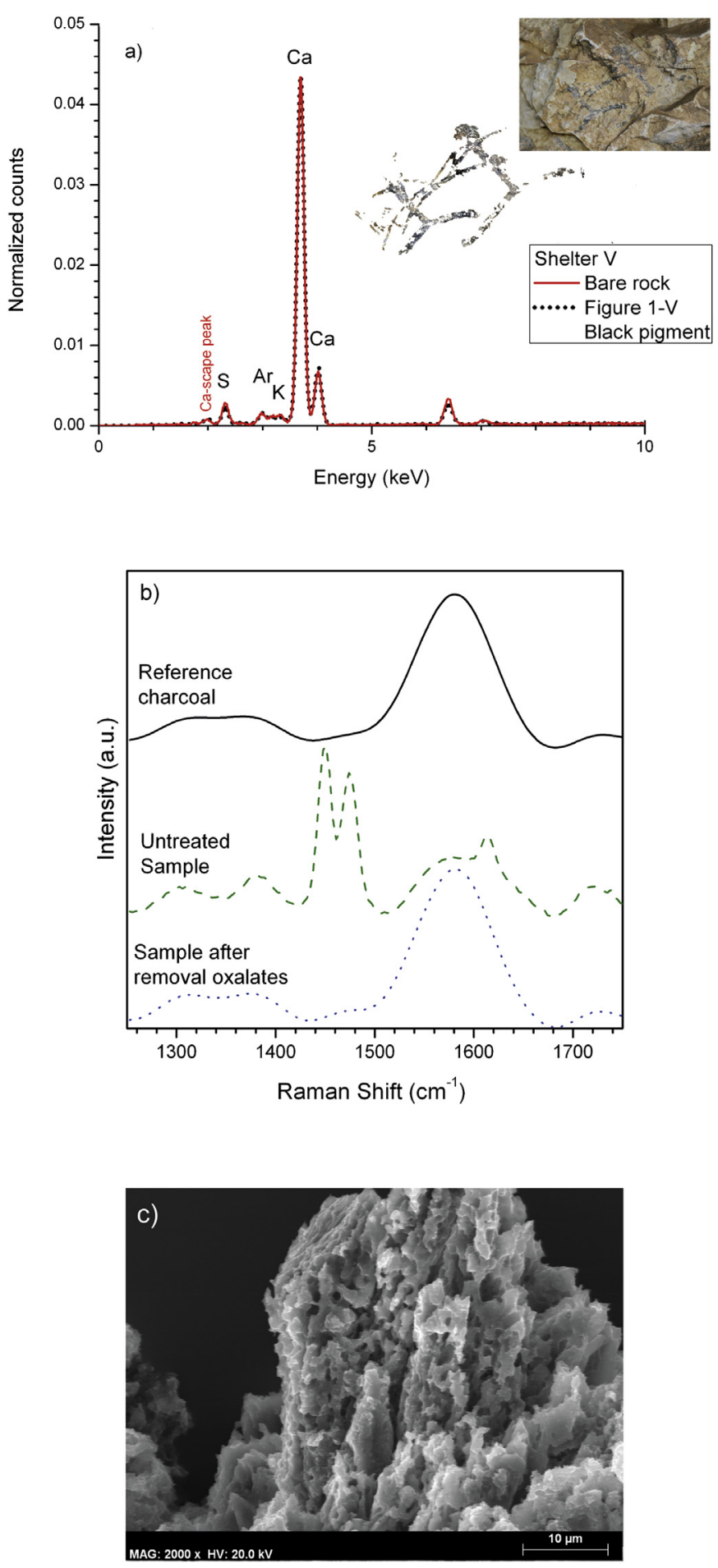

Fig. 3. a. Black pigment and bedrock EDXRF spectra from the human figure $1-V$. The fact that both spectra are indistinguishable suggests the use of carbon-based black pigment. b. Raman spectra of black pigment samples from the human figure $1-\mathrm{V}$. Solid line: reference charcoal black; dashed line: black pigment on oxalate crush; dotted line: black sample after removal oxalates. c. SEM micrograph of the black pigment from the human figure $1-\mathrm{V}$. capability of the portable EDXRF spectrometer to identify parietal pigments based on manganese black, bone black or charcoal black, we prepared surrogate samples by applying these three pigments on a limestone surface and we compared the EDXRF spectra from pigmented and non-pigmented areas. XRF spectra shown in Fig. 2 contain the detected elements that distinguish the black pigment from the rock support: $\mathrm{Mn}$ in the case of manganese black (Fig. 2a) and $\mathrm{P}$ in the case of ivory black (Fig. 2b). When the applied black pigment is charcoal, the EDXRF spectra of the limestone and the black pigment are indistinguishable (Fig. 2c). In the case of Cova Remigia, black pigments and rock surface EDXRF spectra (Fig. 3a) are indistinguishable. This indicates that the black pigment consists of light elements that cannot be detected by EDXRF analysis, which leads us to conclude that carbon-based black pigments were used, and to reject the use of mineral black pigments due to the absence of key elements such as manganese, iron and copper which are part of the oxides and sulphides characteristic of black earths.

In order to positively identify these black pigments, microscopic samples from one black human figure $(1-\mathrm{V})$ were scraped and analysed by Raman and SEM-EDS to obtain detailed information regarding its elemental composition, molecular structure and morphology (Smith et al., 1999; Edwards et al., 2000; Tomasini et al., 2012; Bonneau et al., 2012). The collected samples included portions of black pigment adhered to spallated fragments of the substrate and covered by calcareous accretions. Raman measurements were made directly on black pigments with calcareous accretions and on black particles that were extracted from the surrounding calcium compound with 1 M EDTA and an ultrasonic bath at room temperature. Raman microanalysis of the black pigment particles from the human figure $1-\mathrm{V}$ present two broad bands at $c a 1330 \mathrm{~cm}^{-1}$ and $c a 1580 \mathrm{~cm}^{-1}$, characteristic of amorphous carbon (Fig. 3b). In this sample, the band at ca $961 \mathrm{~cm}^{-1}$ (typical of the hydroxyapatite) and the bands at ca 620 and $670 \mathrm{~cm}^{-1}$ (typical of the manganese oxides) are not present, so bone black and manganese black oxides are excluded as raw materials. Raman spectra of the untreated samples show oxalate bands at the range of $1200-1700 \mathrm{~cm}^{-1}$.

SEM morphology of black pigments showed amorphous particles mixed with black particles that can be related to the morphology of the raw material (Badal, 1987-1988). Probably, these char particles come from partly pulverized cell wall structures, channels and holes associated to the dehydration of wood, and consequently the morphological features are difficult to see (Fig. 3c). The micro-EDS analyses of the amorphous particles show abundance of sulphur and calcium, which indicates the presence of calcium sulphate. Black particles of the sample indicate that carbon is the main element and calcium and potassium are minor elements.

Taking into account both the EDXRF analyses and the results of the Raman and SEM analyses of the motif $1-\mathrm{V}$, we can postulate the use of carbon-based black pigments as raw material not only for this motif but also for the 24 other motifs analysed in Cova Remigia. The thickness and intensity of the paint layers and surface patinas are highly variable. Therefore, it makes no sense to undertake a quantitative study since the aim of this paper is to present qualitative data relative to the discriminatory elements detected in pigmented areas and the rock surface.

\subsection{Stylistic approaches}

Focussing on social aspects involved in the selection of raw materials, the preparation mode and the use of prehistoric pigments, two main ideas emerge from the results obtained in Cova Remigia: a different and an unusual pattern in the choice of vegetal carbon to obtain black colour and in the manner and frequency 
with which these carbon-based black pigments were used in some panels.

Regarding the use of black pigment, Cova Remigia is exceptional for various reasons. Firstly, due to the large number of figures executed in black- 48 identifiable figures, plus a large quantity of strokes and stains that are difficult to count and identify due to their bad preservation -. Black pigments were used interchangeably to draw human and animal figures showing a formal variability that suggest the use of black pigments at different moments during the diachronic construction of the panels. Secondly, due to the technical aspects associated with their use. Some of the figures originally painted in black have been subjected to later transformations. The modifications can consist in a formal change (repainting) or in the addition of new elements, which indicates a graphical and narrative re-appropriation. In both cases, this transformation involved an intentional use of two colours combinations - red and black-, which is a rare practice in Levantine rock art.

It is necessary to assess a stylistic and technical study of these black motifs in order to characterize the presence of patterns or recurrent rules that can help us to decrypt the social codes that regulate the use of carbon-based black pigments at this site.

\subsubsection{Monochromatic motifs}

The 48 monochromatic motifs executed originally in black show a significant spatial concentration in shelters IV and $\mathrm{V}$, being particularly abundant in the second (Tables 1 and 2).

Our stylistic assessment includes all these figures, even those that were repainted in red during a later stage. Our objective is to determine the beginning and the temporal extension of the use of carbon-based black pigments and the advent of appropriation and repainting/reconstruction phases of certain figures by using red pigments. In order to do that, we will take into account the stylistic sequence previously established for the Valltorta-Gassulla area
(Villaverde et al., 2002; Domingo, 2006; López Montalvo, 2007; etc.).

The design of black human figures, even if we observe some formal variations, points to the recurrent use of carbon-based black pigments during the latest phases of the stylistic regional sequence - so-called Linear horizon- characterized by a trend that tended towards formal simplification with important variations concerning the anatomical proportion, the modelling strokes and the way ornaments and weapons are depicted (Villaverde et al., 2002; Domingo, 2006; López Montalvo, 2007). However, the presence of two human figures showing different formal features from those described above and even the formal variations perceived in these linear figures (Fig. 4) led us to believe that different authors, probably in different times, contributed to the panel.

Regarding animal figures, the use of black pigments is not exclusively limited to particular species or type of design (different anatomical proportions, perspectives, movement or drawing accuracy). Again, these variations suggest a temporal amplitude and/ or the participation of different authors. Wild male and female goats, a species that is commonly represented in Valltorta-Gassulla, is also the most common species depicted in black. A wild boar and a female deer in inverted position have also been documented (Fig. 5).

\subsubsection{Two-colour figures: repainting, reconstruction and graphical and narrative appropriation}

Some of the black motifs described above have been subjected to transformation processes such as total or partial repainting in red colour. These processes not only have modified the original shape of the figures but, by the addition of new graphic elements, they have also modified or given a new interpretation to the narrative. EDXRF spectra suggest the use of a carbon-based black pigment for the initial motifs, while the areas repainted in red present a high iron fluorescence peak associated to the use of red iron oxides.

Table 1

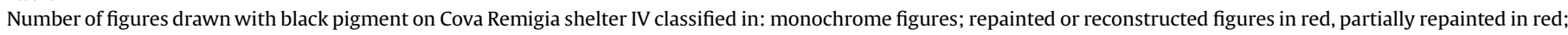
sketches and graphic-narrative appropriations.

\begin{tabular}{|c|c|c|c|c|c|c|}
\hline Shelter IV & Monochrome & Two-colours repainted & Two-colour partially repainted & Narrative appropiation & Sketch & Total \\
\hline Human figures & 4 & 1 & & & & 5 \\
\hline \multicolumn{7}{|l|}{ Bovids } \\
\hline \multicolumn{7}{|l|}{ Wild goar } \\
\hline \multicolumn{7}{|l|}{ Male deer } \\
\hline Female deer & 1 & & & & & 1 \\
\hline Caprids (undetermined sex) & 1 & & & & & 1 \\
\hline Female/young wild goat & 1 & & & & & 1 \\
\hline Male wild goat & 1 & 1 & 1 & & 1 & 4 \\
\hline Unidentified motif & 3 & & & & & 3 \\
\hline Total & 11 & 2 & 1 & & 1 & 15 \\
\hline
\end{tabular}

Table 2

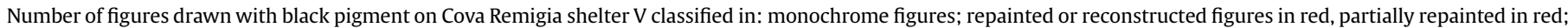
sketches and graphic-narrative appropriations.

\begin{tabular}{|c|c|c|c|c|c|c|}
\hline Shelter V & Monochrome & Two-colours repainted & Two-colour partially repainted & Narrative appropiation & Sketch & Total \\
\hline $\begin{array}{l}\text { Human figures } \\
\text { Bovids }\end{array}$ & 9 & 10 & & 1 & & 20 \\
\hline Wild goar & & 1 & & 1 & & 2 \\
\hline Male deer & & & & & & \\
\hline Female deer & & & & & & \\
\hline Caprids (undetermined sex) & & & & & & \\
\hline $\begin{array}{l}\text { Female/young wild goat } \\
\text { Male wild goat }\end{array}$ & & & 1 & & & 1 \\
\hline Unidentified animal species & 1 & & & & & 1 \\
\hline Unidentified motif & 7 & & 1 & & & 8 \\
\hline Animal track & 1 & & & & & 1 \\
\hline Total & 18 & 11 & 2 & 2 & & 33 \\
\hline
\end{tabular}




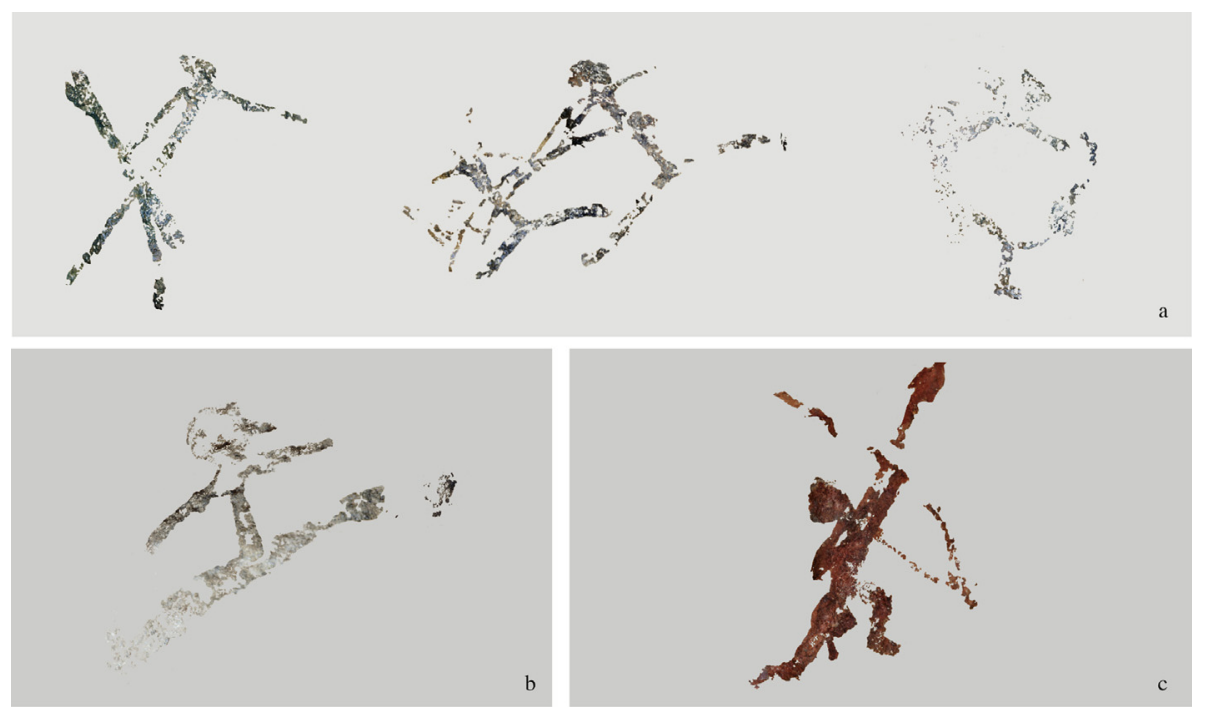

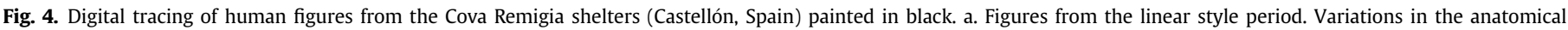
proportions and the stroke can be appreciated. b-c. Black human figures belonging to other unclassifiable stylistic periods.

In the light of the examples documented at Cova Remigia, different processes leading to two-colour combination can be described.

4.2.2.1. Repainting processes. We suggest that the two-colour combination observed in Cova Remigia is the result of a diachronic repainting that often involves the modification of the silhouettes and the proportion of figures originally executed with black pigments, with the intention of distinguishing the repainting phase. We adopt this view not only because a different colour was used, but also for technical reasons. For instance, in the case of the archer squad or the archer hunting the wild goat in shelter IV (Fig. 6), the difference in the repainting may be due either to a less skilled painter or to the use of less precise "brushes" creating rough and careless silhouettes. Therefore, this two-colour combination does not seem to be connected to an intentional and synchronic combination of colours for the original design of the figures. However the time span between the two execution phases cannot be easily established. In this sense, it is worth noting that some Linear style figures, belonging to the last stages of the stylistic regional sequence, such as the archer squad, were also repainted. This indicates that repainting practises took place, at least to some extent, during the later stages of the execution of the paintings in this shelter (Insert Supplementary Fig. 3 here).

Sixteen out of the 48 figures originally depicted with black pigments were repainted (Tables 1 and 2). The chromatic sequence
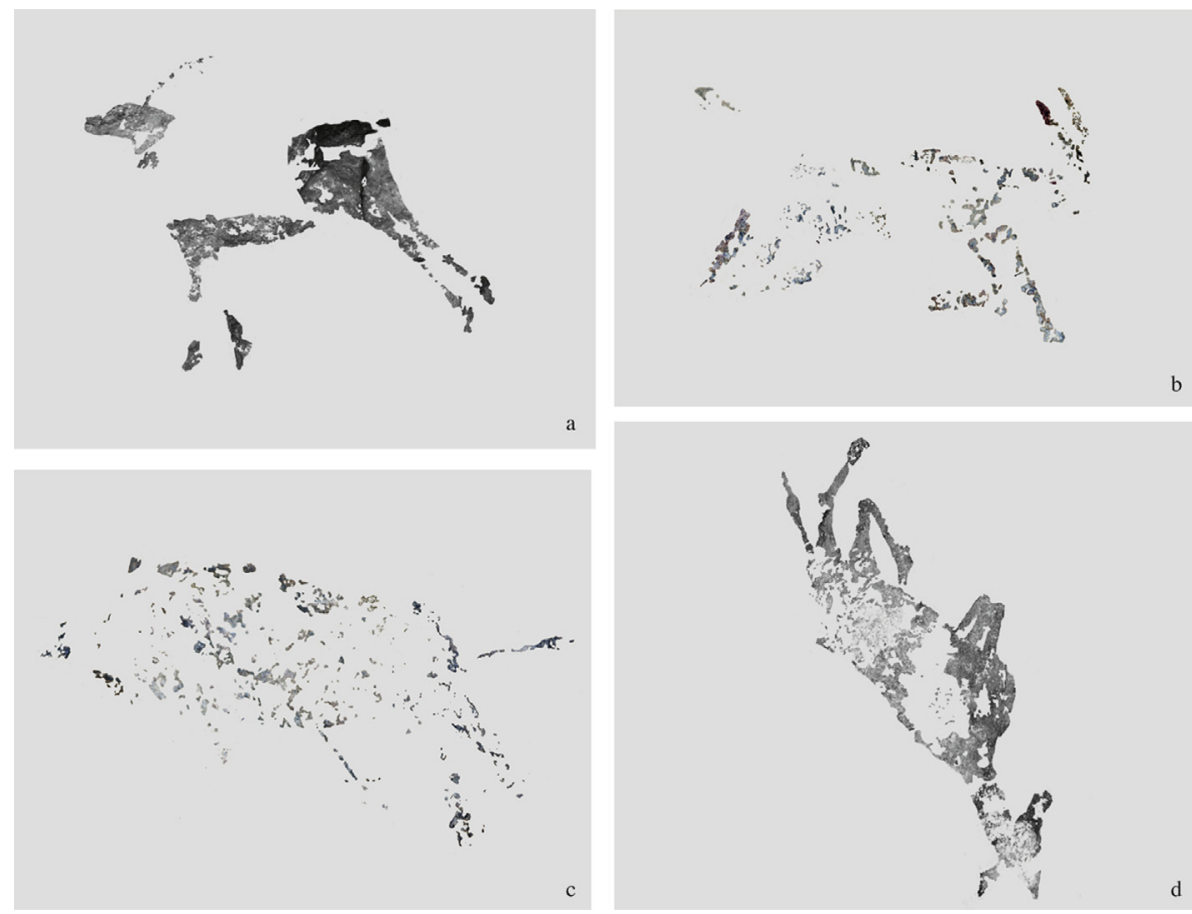

Fig. 5. Digital tracing of animal figures painted in black from the Cova Remigia shelters. a-b. Goat. c. Wild goar. d. Female deer. 
in all these cases was identical: the original design made in black can be observed currently both under the red pigment layer, using colour filters, and on the edges, where it is not entirely covered by the added red pigment. Not only does the red repainting not fit exactly the original black outline, probably due to an intentional rectification of the anatomical proportions, but the red strokes are rough in contrast to the more accurate ones painted in black (Fig. 6).

Lastly, one goat of Shelter V (Fig. 7) shows some differences, which can be appreciated after comparing with the cases mentioned above. This is one of the rare instances of an animal figure being partially repainted with red. Differences between both execution phases are clearly shown, not only by the colour of the pigments, but also by the quality of the execution itself. The small and delicately painted black figure contrasts again with the rough and careless red stroke.

A technical assessment of these repainting processes led us to discard the use of carbon-based black pigments to make a preliminary sketch of figures, completed later with red pigment. Firstly, because the preliminary sketches, often found in Levantine paintings, are always executed in the same hue but with a lighter tone that is hardly perceptible on limestone (López Montalvo, 2008, 2011b). Secondly, only 33\% of the figures executed in black were repainted in red, which shows that the transformation was not systematic, as it should be in the case of synchronic sketch and execution.

We must conclude that this two-colour combination documented in Cova Remigia is certainly different to the two-colour red and white - synchronic combination (bichromie) documented in earlier stylistic phases of Valltorta-Gassulla, and is probably linked to the will to distinguish the repainting process by using a different colour and modifying the silhouettes and proportions of original monochromatic figures.
4.2.2.2. Graphic narrative appropriation. Two-colour combination is also found in cases where there is no formal transformation but a narrative re-appropriation of the existing figures. Only two cases have been found in Cova Remigia: a wild boar (Fig. 8a) and one of the human figures shot by the execution squad described above (Fig. 8b). In both cases appropriation is shown by the addition of one or several big red arrows crossing the figure, but in none of these cases we observe a transformation of the original narrative, as both figures were already shot by arrows in the earlier version. Nevertheless, it is possible that the graphic-narrative appropriation coincides with the repainting phase exposed above, at least in the case of the execution scene.

We must point out that similar cases of graphic appropriation can be found in many Levantine sites. They are clearly identifiable by differences in tone and density of the pigments used for the arrows added to animal and human figures. Nevertheless, this is the first time that appropriation by means of different colour has been documented in this area.

\section{Conclusions}

For the first time, carbon-based black pigments have been identified in northern regions of the Levantine territory, and they were repeatedly used in the Cova Remigia shelters. These findings completely change the technical patterns known so far in the Valltorta-Gassulla area, where black colour was rare, while analyses have proven the use of manganese as raw material (Roldán et al., 2007, 2010).

EDXRF analyses allowed us to identify the carbonaceous nature of black pigments in 25 figures from Cova Remigia, and led us to propose the use of carbon-based black pigments (probably charcoal) as raw material. The presence of carbon in the black pigments
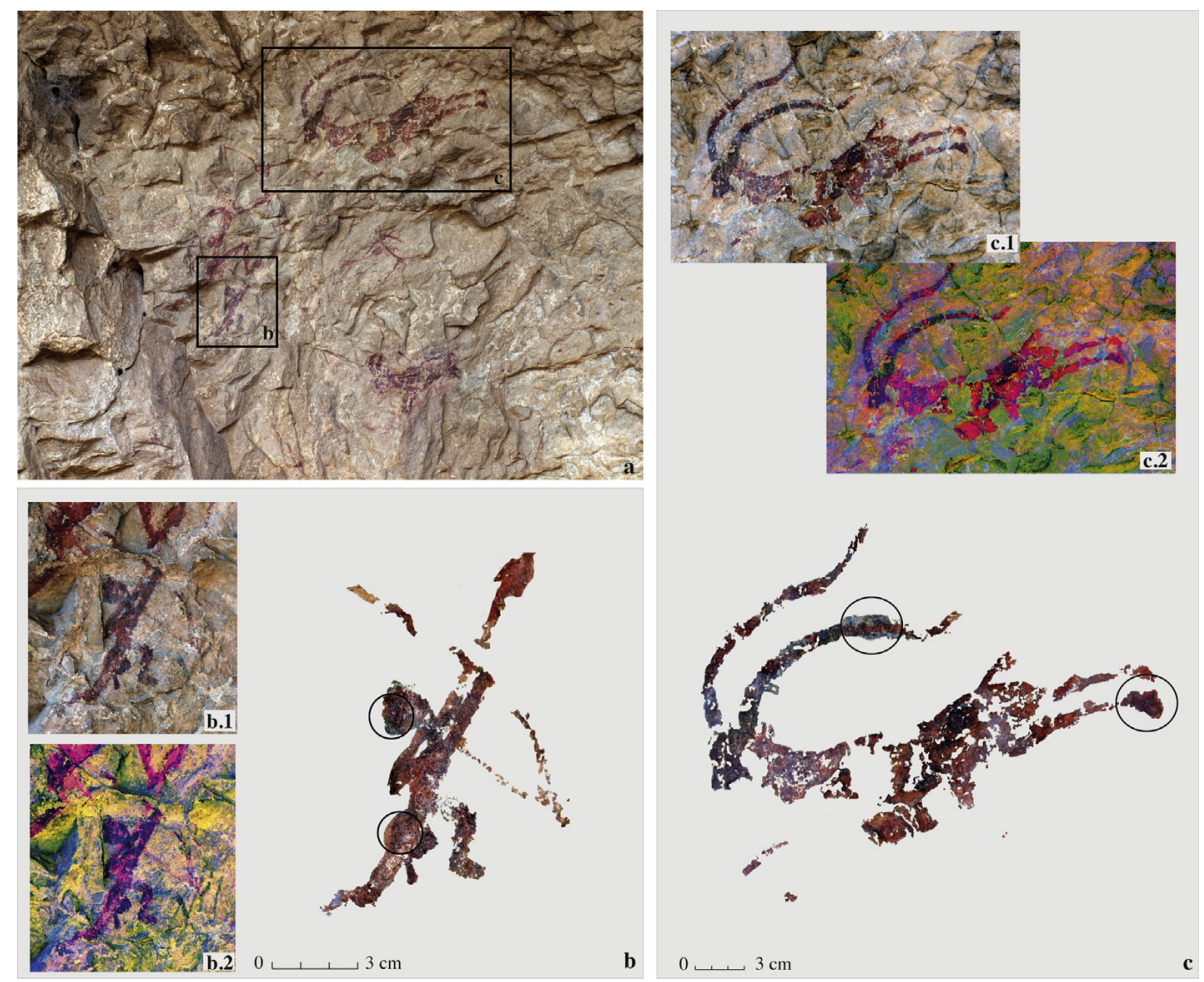

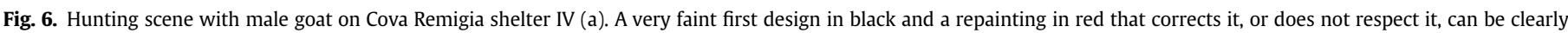

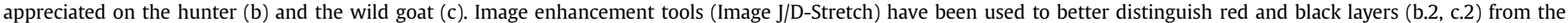

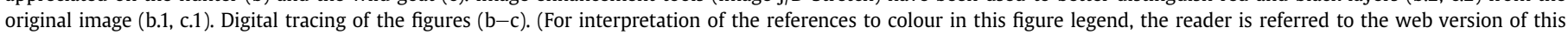
article.) 

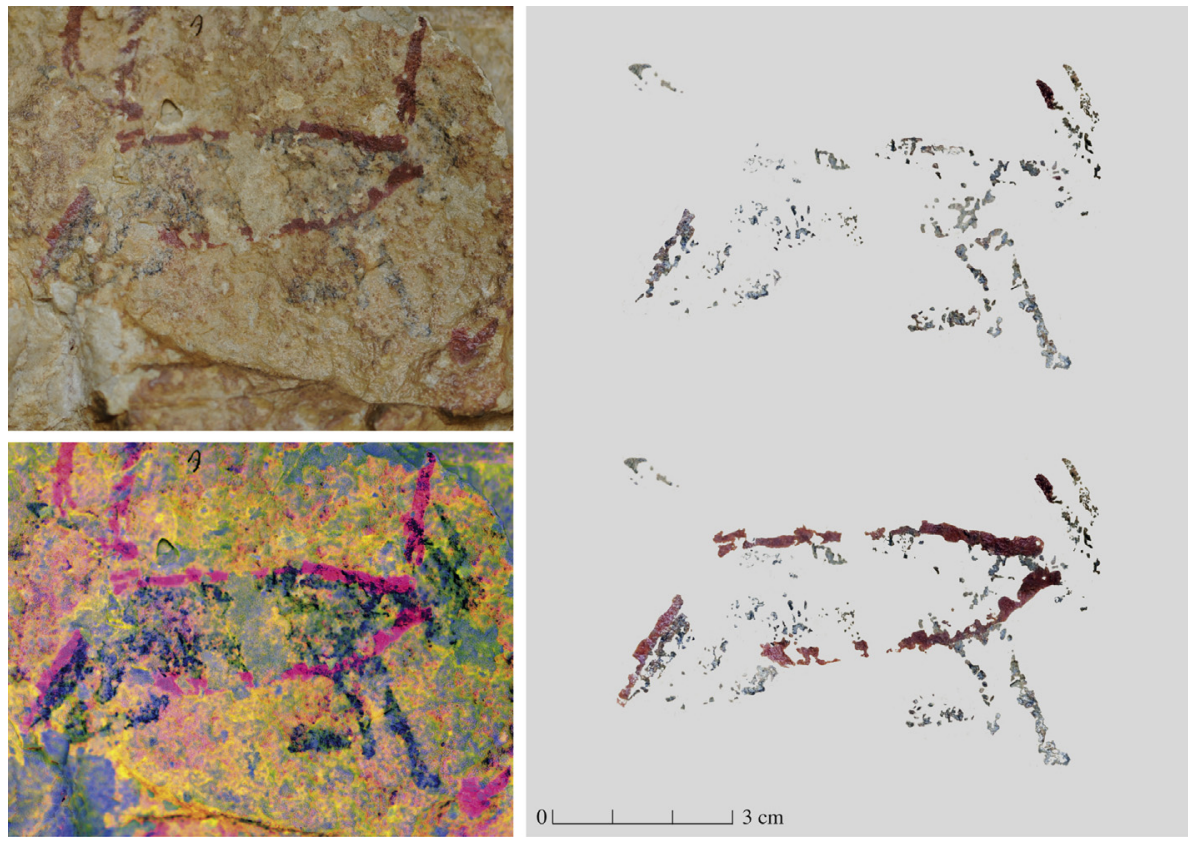

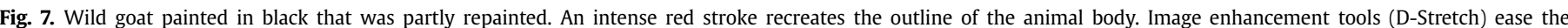

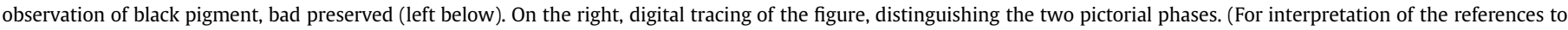
colour in this figure legend, the reader is referred to the web version of this article.)
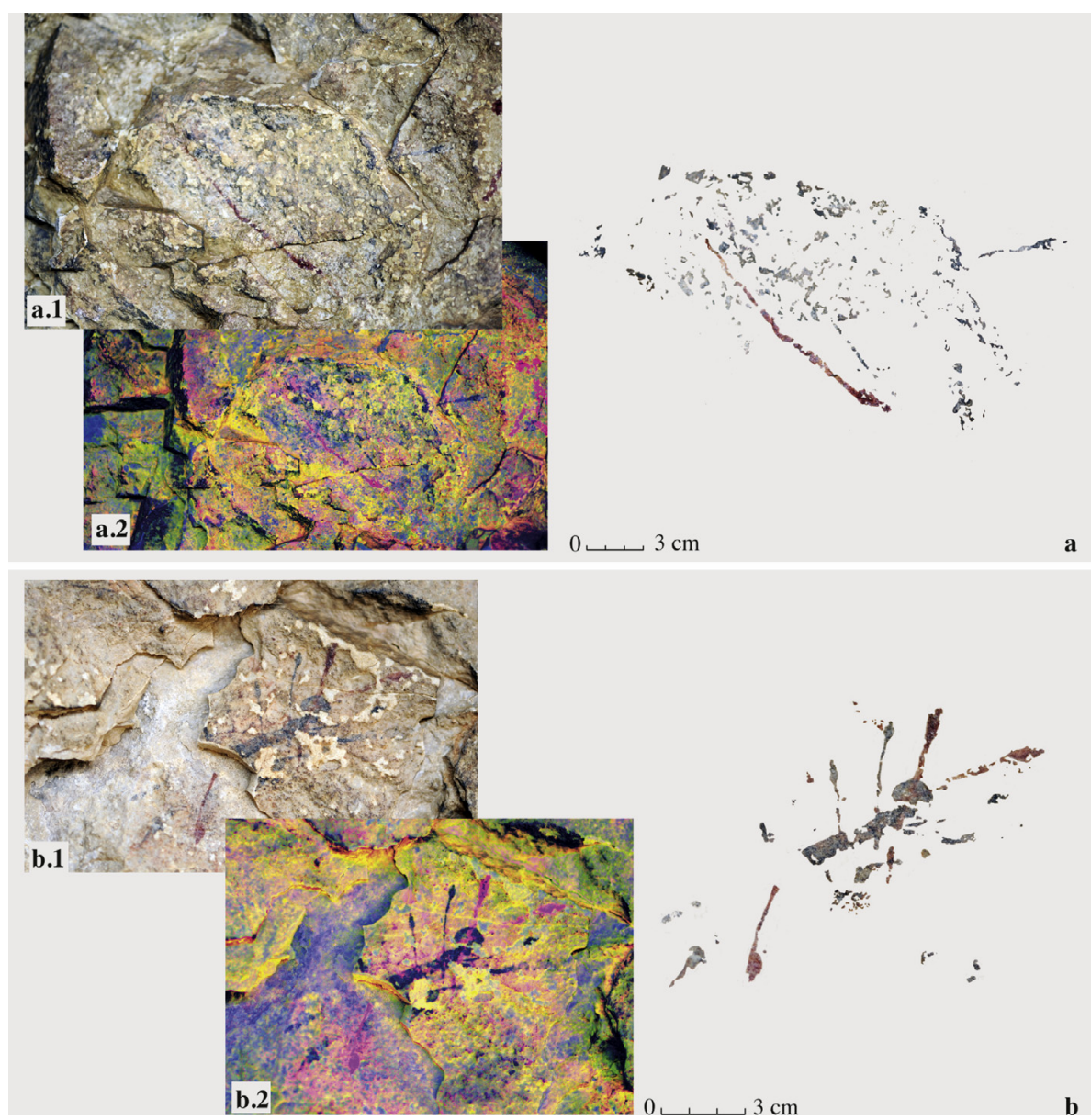

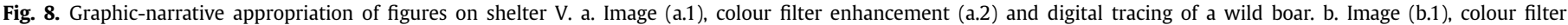

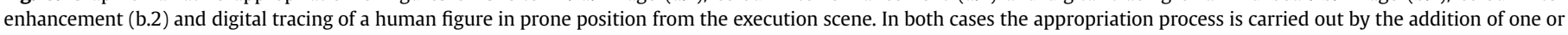
several red arrows in red. (For interpretation of the references to colour in this figure legend, the reader is referred to the web version of this article.) 
has been positively confirmed in micro-samples analysed by Raman spectroscopy and SEM-EDS analysis, which is in agreement with the hypothesis derived from EDXRF analysis. Therefore, portable and non-destructive techniques as EDXRF spectrometry, combined with SEM-EDS and Raman spectroscopy, are suitable for determining the nature of black pigments used in Spanish Levantine rock art.

The stylistic and technical analyses of figures painted with carbon-based black pigment in Cova Remigia point to particular patterns with respect to the use of this pigment. First of all, the number of well-preserved figures, even if it is smaller than the red ones, questions the idea, so far accepted in spite of weak evidences, that black was hardly used in this environment. It is worth noting that carbon-based black pigments could be less resistant to weathering conditions than mineral-based pigments, so it is possible that the original number of figures was higher, as the remains of incomplete and badly-preserved black motifs seem to indicate. Secondly, the stylistic features of black figures suggest that the use of carbon-based black pigments was more extensive during the last phases of the stylistic sequence of Valltorta-Gassulla. Finally, one of the most interesting patterns in the use of carbonbased black pigments is the transformation of some of these figures by means of two-colour combination. This can be a result of a repainting/reconstruction process or by a graphic re-appropriation. Through the analyses carried out at Cova Remigia we can establish that this two-colour combination originates in a phase which is posterior to the original execution of the figures. It is either the product of a complete repainting of figures with a red pigment, basically haematite, where rectification of silhouettes and proportion, sometimes less precise, can be observed, or the addition of narrative "nexus," in the form of arrows that impact on human or animal figures reinforcing the appropriation of the original narrative. Exceptionally, we can also observe a partial overlapping of the silhouette. It is not possible to establish the time span between the two pictorial phases. However, taking into account that some of the repainted figures belong to the terminal phases of Levantine cycle, repainting processes have taken place, at least to some extent, during the last stages of rock art elaboration in Cova Remigia.

The identification of carbon-based black pigments in Cova Remigia is the starting point for future studies. First of all, the characterization of the chaîne opératoire of pigments, handling in order to get a better knowledge of the raw materials and their preparation processes, can lead to an appraisal of the social codes that regulate their utilisation. Finally, the identification of carboncontaining pigments opens the possibility of radiocarbon dating, which could be a crucial step in establishing the chronology and authorship of Spanish Levantine rock paintings.

\section{Acknowledgements}

The results presented in this paper are part of the projects PROMETEO/2008-165 and PROMETEOII/2013-016 of the Generalitat Valenciana Excellence Programme directed by Dr. Valentín Villaverde. The research of one of the authors is also developed in the frame of the project ANR-10-CREA-001 as well as the "NEOSOCWESTMED" project ( $\mathrm{n}^{\circ}$ 628428) of the Marie Curie Actions of the 7th Framework Research Programme of the European Commission.

We would like to thank the Government of Valencia - Conselleria d'Educació, Cultura i Esport-Direcció General de Patrimoni Cultural-for allowing us to carry out the analyses of pigments. We also thank Dr. O. Rivero and Dr. G. Sauvet for their comments regarding this paper and Dr. J.M del Hoyo-Meléndez for proofreading the final manuscript. Special thanks to Dr. L. Ballester, Ms. J. Carballo and Mr. T. Gómez for their help during the in situ analyses.

\section{Appendix A. Supplementary data}

Supplementary data related to this article can be found at http:// dx.doi.org/10.1016/j.jas.2014.09.017.

\section{References}

Alloza, R., Arranz, E., González Grau, J.M., Baldellou, V., Resano, M., Marzo, P., Vanhaecke, F., 2009. La conservación del arte rupestre: estudio de los factores de deterioro y la composición química de los pigmentos. In: López-Mira, J. Matamoros, C., Martínez-Valle, R. (Eds.), Actas del IV Congreso “El Arte Rupestre del Arco Mediterráneo de la Península Ibérica". Generalitat Valenciana, Valencia, pp. 317-326.

Arias, P., Laval, E., Menu, M., González-Sainz, C., Ontañón, R., 2011. Les colorants dans l'art pariétal et mobilier paléolithique de La Garma (Cantabrie, Espagne). L'Anthropologie 115, 425-445.

Badal, E., 1987-1988. La Antracología: método de recogida y estudio del carbón prehistórico. Saguntum 21, 169-182.

Ballester, L., Guillamet, E., Mazzoni, A., Poggi, D., 2010. Abrigo de Ciervos Negros Nota sobre la determinación patol. pigmento negro. In: Mateo Saura, M.A. Sicilia Martínez, E. (Eds.), El Abrigo de Ciervos Negros (Moratalla, Murcia). Tres Fronteras. Conserjería de Cultura y Turismo. Región de Murcia, Murcia, pp. $127-133$.

Beltrán, A., 1968. Arte rupestre levantino. Monografías arqueológicas, 4. In: Seminario de Prehistoria y Protohistoria, Facultad de Filosía y Letras. Zaragoza.

Bonneau, A., Pearce, D.G., Pollard, A.M., 2012. A multi-technique characterization and provenance study of the pigments used in San rock art, South Africa. J. Archaeol. Sci. 39, 287-294.

Cabré, J., 1915. El Arte Rupestre en España (Regiones Septentrional y Oriental). Comisión de investigaciones paleontológicas y prehistóricas, 1. Museo de Ciencias Naturales, Madrid.

Cabré, J., 1925. Las pinturas rupestres de la Valltorta. Escena bélica de la Cova del Cevil. Actas Memorias la Soc. Española Antropol. Etnología Prehist. III-IV, 201-233.

Chalmin, E., Menu, M., Vignaud, C., 2003. Analysis of rock art painting ad technology of Paleolithic painters. Meas. Sci. Technol. 14, 1590-1597.

Clottes, J., 1993. Paint analyses from several Magdalenian caves in the Ariège region of France. J. Archaeol. Sci. 20, 223-235.

Domingo, I., 2006. La figura humana, paradigma de continuidad y cambio en el Arte Rupestre Levantino. Arch. Prehist. Levantina XXVI, 161-191.

Domingo, I., López-Montalvo, E., Villaverde, V., Martínez, R., Guillem, P.M., 2003. Las pinturas rupestres del Mas d’En Josep (Tírig, Castelló). Consideraciones sobre la territorialización del Arte Levantino a partir del análisis de las figuras de bóvidos y jabalíes. Saguntum-PLAV 35, 9-50.

Domingo, I., López-Montalvo, E., Villaverde, V., Martínez, R., 2007. Los abrigos VII, VIII y IX de La Saltadora (Coves de Vinromà, Castelló). Monogr. del Mus. la Valltorta 2. Generalitat Valenciana, Valencia).

Edwards, H.G.M., Newton, E.M., Russ, J., 2000. Raman spectyroscopic analysis of pigments and substrata in prehistoric rock art. J. Mol. Struct. 550-551, 245-256.

García, O., Molina, Ll, García-Robles, R., 2004. El arte levantino y el proceso de neolitización en el arco mediterráneo peninsular : el contexto arqueológico y su significado. Arch. Prehist. Levantina XXV, 61-90.

Hernanz, A., Gavira-Vallejo, J.M., Ruiz-López, J.F., 2006. Introduction to Raman microscopy of prehistoric rock paintings from Sierra de las Cuerdas, Cuenca, Spain J. Raman Spectrosc. 37, 1054-1062.

Hernanz, A., Gavira, J.M., Ruiz, J.F., Edwards, H.G.M., 2008. A Comprehensive MicroRaman Spectroscopic Study Of Prehistoric Rock Paintings From The Sierra de las Cuerdas, Cuenca, Spain. J. Raman Spectrosc. 39, 972-984.

Hernanz, A., Ruiz-López, J.F., Gavira_Vallejo, J.M., Martín, S., Gavrilenko, E., 2010. Raman microscopy of prehistoric rock paintings from the Hoz de Vicente, Minglanilla, Cuenca, Spain. J. Raman Spectrosc. 41, 1394-1399.

Hernanz, A., Ruiz-López, J.F., Gavira_Vallejo, J.M., 2012. Pigmentos, aglutinantes y patinas: caracterización fisicoquímica de las pinturas rupestres levantinas. In: García, J., Collado, H., Nash, G. (Eds.), The Levantine Question. Ed. Archeolingua, Budapest, pp. 345-366.

López Montalvo, E., 2007. El análisis interno del Arte Levantino: la composición y el espacio a partir de la sistematización del núcleo Valltorta-Gassulla. Publicacions de la Universitat de València, Valencia.

López Montalvo, E., 2008. Cuestionando la improvisación : pautas de corrección y planteamiento espacial en los abrigos levantinos del núcleo Valltorta-Gassulla (Castelló). In: Hernández, M., Soler, J., López, J.A. (Eds.), Actas el IV Congreso del Neolítico Peninsular. Museo Arqueológico de Alicante, Alicante, pp. 31-36.

López Montalvo, E., 2009. Caracterización de la secuencia levantina a partir de la composición y el espacio gráfico: el núcleo Valltorta-Gassulla como modelo de estudio. In: López, J.A., Martínez, R., Matamoros, C. (Eds.), Actas del IV Congreso del arte rupestre del Arco Mediterráneo de la Península Ibérica. Generalitat Valenciana, Valencia, pp. 81-94.

López Montalvo, E., 2011a. La violence et la mort dans l'art rupestre du Levant espagnol : groupes humains et territoire. In: Baray, L., Honegger, M., DiasMeirinho, M.H. (Eds.), L’armement et l'image du guerrier dans les sociétés anciennes. De l'objet à la tombe. Ed. Universitaires de Dijon, Dijon, pp. 19-42. 
López Montalvo, E., 2011b. La sociedad a través del gesto : aportaciones de los abrigos rupestres del Bajo Aragón (Teruel) y l'Alt Maestrat (Castelló) a la definición de la cadena operativa del Horizonte de figuras cestosomáticas. In: López-Montalvo, E., Sebastián, M. (Eds.), El Legado Artístico de las Sociedades Prehistóricas. Nuevos Paradigmas de Análisis y Documentación. Universidad de Zaragoza, Zaragoza, pp. 79-84.

Martí, B., 2003. El arte rupestre levantino y la imagen del modo de vida cazador: entre lo narrativo y lo simbólico. In: Tortosa, T., Santos, J.A. (Eds.), Arqueología e iconografía. Indagar en las imágenes. L'Erma di Bretschneider, Italia, pp. 59-75.

Martí, B., Juan-Cavanilles, J., 2002. La decoració de les ceràmiques neolítiques i la seua relació amb les pintures rupestres dels Abrics de la Sarga. In Hernández, M.S., Segura, J.Mª (Eds.), La Sarga : Arte Rupestre Y Territorio. Caja de Ahorros del Mediterráneo, Alicante, pp. 147-170.

Martí, B., Juan-Cavanilles, J., 2013. La colección lítica de Cantos de la Visera (Yecla, Murcia) depositada por H. Breuil en el Museo de Prehistoria de Valencia. In: de la Rasilla Vives, M., Javier Fortea Pérez, F. (Eds.), Universitatis Ovetensis Magister. Estudios en Homenaje. Universidad de Oviedo. Ménsula Ediciones, Oviedo, pp. $467-481$.

Mas, M., Jorge, A., Gavilán, B., Solís, M., Parra, E., Pérez, P., 2013. Minateda rock shelters (Albacete) and post-palaeolithic art of the Mediterranean Basin in Spain: pigments, surfaces and patinas. J. Archaeol. Sci. 40, 4635-4647.

Mateo Saura, M., 2005. En la controversia de la cronología del Arte rupestre Levantino. Cuad. Arte Rupestre 2, 127-156.

Mateo Saura, M., 2009. Arte Rupestre Levantino. Cuestiones de Cronología y Adscripción Cultural. Ed. Tabularium, Murcia.

Menu, M., Walter, Ph, 1996. Les rythmes de l'art préhistorique. Techne 3, 11-23.

Menu, M., 2009. L'analyse de l'art préhistorique. L'Anthropologie 113, 547-558.

Molina, Ll, García Puchol, O., García-Robles, R., 2003. Apuntes al marco crono-cultural del arte levantino : Neolítico vs neolitización. Saguntum-PLAV 35, 51-67.

Montes, R., Cabrera, J.M., 1991-1992. Estudio estratigráfico y componentes pictóricos en el arte prehistórico de Murcia (Sureste de España). An. Prehist. Arqueol. 7-8, 69-74

Olivares, M., Castro, K., Corchón, M.S., Gárate, D., Murelaga, X., Sarmiento, A., Etxebarria, N., 2013. Non-invasive portable instrumentation to study Palaeolithic rock paintings: the case of La Peña Cave in San Roman de Candamo (Asturias, Spain). J. Archaeol. Sci. 40-2, 1354-1360.

Ospitali, F. Smith, B., Lorblanchet, M., 2006. Preliminary investigations by Raman microscopy of prehistoric pigments in the wall-painted cave at Roucadour, Quercy, France. J. Raman Spectrosc. 37-10, 1063-1071.

Piñón Varela, F., 1982. Las pinturas Rupestres de Albarracín (Teruel). Ministerio de Cultura. Dirección General de Bellas Artes, Santander.

Pomiès, M.P., Barbaza, M., Menu, M., Vignaud, C., 1999. Les modes de préparation des pigments préhistoriques (sélection, transformation, mélanges). L'Anthropologie 103, 503, 118 .

Porcar, J.B., 1945. Iconografía Rupestre de Gasulla y Valltorta. Danza de Arqueros ante figuras humanas sacrificadas. Boletín la Soc. Castellon. Cult. XXI, 145-152.

Porcar, J.B., 1946. Iconografía rupestre de La Gasulla y Valltorta: escenas bélicas. Boletín la Soc. Castellon. Cult. XXII, 48-62.

Porcar, J.B., Obermaier, H., Breuil, H., 1935. Excavaciones en la Cueva Remigia (Castellón). Memoria de la Junta Superior del Tesoro Artístico, Madrid.

Resano, M., García, E., Alloza, R., Marzo, M., Vandenabeele, P., Vanhaecke, F. 2007. Laser ablation-inductively coupled plasma Mass Spectrometry for the characterization of pigments in prehistoric rock art. Anal. Chem. 79 (23), 8947-8955.

Roldán, C., 2009. Análisis de pigmentos en conjuntos de arte rupestre. In: López, J.A Martínez, R., Matamoros, C. (Eds.), Actas del IV Congreso El arte Rupestre de arco Mediterráneo de la Península Ibérica. Generalitat Valenciana, Valencia, pp. 269-278.

Roldán, C., Ferrero, J., Murcia-Mascarós, S., Villaverde, V., Martínez, R., Guillem, P.M., Domingo, I., López, E., 2007. Análisis in situ de pigmentos de las pinturas rupestres de los abrigos VII, VIII y IX de la Saltadora mediante fluorescencia de Rayos-X. In: Domingo, I., López-Montalvo, E., Villaverde, V., Martínez, R. (Eds.) Los abrigos VII, VIII y IX de Coves de la Saltadora (Les Coves de Vinromà, Castelló). Generalitat Valenciana, Valencia, pp. 191-209.

Roldán, C., Murcia, S., Ferrero, J., Villaverde, V., López, E., Domingo, I., Martínez, R. Guillem, P., 2010. Application of field portable EDXRF spectrometry to analysis of pigments of Levantine rock art. X-Ray Spectrom. 39, 243-250.

Roldán, C., Villaverde, V., Ródenas, I., Novelli, F., Murcia, S., 2013. Preliminary analysis of Palaeolithic black pigments in plaquettes from the Parpalló cave
(Gandía, Spain) carried out by means of non-destructive techniques. J. Archaeol. Sci. 40, 744-754.

Roldán, C., Villaverde, V., Ródenas, I., López, E., Domingo, I., Murcia, S., Martínez, R., Guillem, P., 2014. Análisis de pigmentos parietales de Arte Levantino de los abrigos del "Cingle de la Mola Remigia" (Barranco de la Gasulla, Castellón). In: Proceedings of the "X Congreso Ibérico de Arqueometria" (Castellón, 16-18th October, 2013).

Ruiz, J.F., 2006. Las pinturas rupestres en la Serranía de Cuenca. Análisis, revisión y crítica del concepto de estilo en las manifestaciones plásticas postpaleolíticas (Ph. D. thesis, Unpublished). UNED, Madrid.

Ruiz, J.F., Mas, M., Hernanz, A., Rowe, M.W., Steelman, K., Gavira, J.M., 2006. First radiocarbon dating of oxalate crusts over Spanish prehistoric rock art. Int. News Rock Art 46, 1-5.

Ruiz, J.F., Rowe, M.W., Hernanz, A., Gavira, J.M., Viñas, R., Rubio, A., 2009. Cronología del arte rupestre postpaleolítico y datación absoluta de pátinas de oxalato cálcico. Primeras experiencias en Castilla- La Mancha (2004-2007). In: López, J.A., Martínez, R., Matamoros, C. (Eds.), Actas del IV Congreso El arte Rupestre del arco Mediterráneo de la Península Ibérica. 10 años en la Lista del Patrimonio Mundial de la UNESCO. Generalitat Valenciana, Valencia, pp. 303-316.

Ruiz, J.F., 2011. Aplicación in situ de microespectroscopía Raman portátil en abrigos con arte rupestre levantino. Primeras experiencias y resultados. In: LópezMontalvo, E., Sebastián, M. (Eds.), El legado artístico de las sociedades prehistóricas: nuevas aproximaciones teóricas y metodológicas. Prensas universitarias de Zaragoza, Zaragoza, pp. 155-158.

Ruiz, J.F., Hernanz, A., Armitage, R.A., Rowe, M.W., Viñas, R., Gavira-Vallejo, J.M., Rubio, A., 2012. Calcium oxalate AMS 14C dating and chronology of postPalaeolithic rock paintings in the Iberian Peninsula. Two dates from Abrigo de los Oculados (Henarejos, Cuenca, Spain). J. Archaeol. Sci. 39, 2655-2667.

Sanoit, J., Chambellan, D., Plassard, F., 2005. Caractérisation in situ du pigment noir de quelques oeuvres pariétales de la Grotte de Rouffignac à l'aide d'un système portable d'analyse par fluorescence X (XRF). Rev. d'Archéométrie 29, 61-68.

Sarrià Boscovich, E., 1988-1989. Las pinturas rupestres de Cova Remigia (Ares del Maestre, Castellón). Lvcentvm VII-VIII, 7-33.

Smith, D.C., Bouchard, M., Lorblanchet, M., 1999. An initial Raman microscopic investigation of prehistoric rock art in caves of the Querey district, S. W. France. J. Raman Spectrosc. 30, 347-354.

Solé, V.A., Papillon, E., Cotte, M., Walter, P., Susini, J., 2007. A multiplatform code for the analysis of energy-dispersive X-ray fluorescence spectra. Spectrochim. Acta B 62, 63-68. http://pymca.sourceforge.net/.

Tomasini, E. Siracusano, G. Maier, M.S., 2012. Spectroscopic, morphological and chemical characterization of historic pigments base don carbón. Paths for the identification of an artistic pigment. Microchem. J. 102, 28-37.

Utrilla, P., Villaverde, V. (Eds.), 2004. Los Grabados Levantinos del Barranco Hondo. Castellote (Teruel). Universidad de Zaragoza, Zaragoza.

Vázquez, C., Maier, M.S., Parera, S.D., Yacobaccio, H.D., Sola, P., 2011. Black pigments of rock art: identification of inorganic and organic components by combining analytical techniques. IAEA-TECDOC-1669 (Eds.). In: Integration of Nuclear Spectrometry Methods as a New Approach to Material Research. International Atomic Energy Agency, Vienna, pp. 19-24.

Villaverde, V., Guillem, P.M., Martínez, R., 2006. El Horizonte gráfico Centelles y su posición en la secuencia del Arte Levantino del Maestrazgo. Zephyrus LIX, $181-198$.

Villaverde, V., López-Montalvo, E., Domingo, I., Martínez, R., 2002. Estudio de la composición y el estilo. In: Martínez, R., Villaverde, V. (Eds.), La Cova dels Cavalls en el Barranc de la Valltorta. Monografías del Museu de la Valltorta, vol. 1. Generalitat Valenciana, Valencia, pp. 135-189.

Villaverde, V., Martínez, R., Guillem, P., López-Montalvo, E., Domingo, I., 2012. What do we mean by Levantine rock art? In: García, J., Collado, H., Nash, G. (Eds.), The Levantine Question. Ed. Archeolingua, Budapest, pp. 81-115.

Viñas, R., Rubio, A., Ruiz, J.F., 2010. La técnica paleolítica del trazo fino y estriado entre los orígenes del estilo levantino de la Península Ibérica. Evidencias para una reflexión. In: Clottes, J., Bednarik, R. (Eds.), L’art pléistocène dans le monde/ Pleistocene art of the world/Arte pleistocénico del Mundo. IFRAO, Foix, pp. 1-14.

Winter, J., West FitzHugh, E., 2007. Pigments based on carbon. In: Berrie, B.H. (Ed.), Artists' Pigments. A Handbook of Their History and Characteristics, vol. 4. National Gallery of Art, Washington, pp. 1-37. 